\title{
Öğretmenlerin mesleki gelişimi için atölye çalışması modeline dayalı bir uygulamanın geliştirilmesi ve değerlendirilmesi
}

\author{
Internal Sharing Knowledge at Professional Development Process: The Workshop \\ Model
}

Esra TÖRE*

\begin{abstract}
Öz
$\mathrm{Bu}$ çalışmanın amacı, öğretmenlerin mesleki gelişimi için atölye çalışması modeline dayalı bir uygulamanın geliştirilmesi ve değerlendirilmesidir. Nicel ve nitel araştırma yöntemlerinin birlikte kullanıldığı karma modelde yapılan bu çalışmada, 2015 Haziran Dönemi Mesleki Çalışmalar Programı kapsamında İstanbul ilinde bir ilkokulda yalnızca kurum içi kaynaklar kullanılarak mesleki gelişim atölyeleri planlanmış, uygulanmış ve uygulamanın etkililiği sınanmıştır. Atölye çalışmalarının tasarımında öğretmenlerin mesleki yeterlilik ve gereksinimlerinin tespit edildiği kişisel bilgi formlarından ve odak grup görüşmelerinden yararlanılmıştır. Kurum içindeki öğretmenler kendi yeterlilik alanlarında, ihtiyaç duyulan 11 farklı konuda etkinlikler, uygulamalar ve oyunlar tasarlamışlardır. Atölyeler 19'ar kişiden oluşan 2 farklı grupta toplamda 38 öğretmenin katılımı ile dönüşümlü olarak gerçekleştirilmiştir.

2 hafta süren atölye çalışmalarının ardından katılımcı öğretmenlere eğitim değerlendirme anketi yapılmış; katılımcılar "seminer konularının iyi seçildiğini", "atölye çalışmalarının uygulamaya dönük olduğunu", atölyelerin "yeni teknik ve beceriler öğrenmelerini sağladığını" belirtmişlerdir. Sırası ile drama, fen bilgisi etkinlikleri ve deneyler, sportif ve fiziksel etkinlikler, müzik algısı ve hikâye anlatıcılığı atölyeleri katılımcılar tarafından en faydalı atölyeler olarak bulunmuştur. Ayrıca katılımcılara "atölye çalışmalarını siz planlasaydınız neyi daha farklı yapardınız?", "Önümüzdeki yıl programa almamızı istediğiniz konular nelerdir?” soruları yöneltilmiş, katılımcıların önerileri alınmıştır. Öğretmenlerin mesleki gelişimi için atölye çalışması modeline dayalı bir uygulamanın geliştirilmesi ve değerlendirilmesi amacı ile yapılıış bu çalışmanın, farklı katılımcı gruplarında, farklı atölye tasarımları ile tekrarlanmasının faydalı olacağı düşünülmektedir.
\end{abstract}

Anahtar Kelimeler: Atölye çalışması modeli, mesleki gelişim, öğretmen eğitimi

* İstanbul Sabahattin Zaim Üniversitesi, Eğitim Fakültesi, Rehberlik ve Psikolojik Danışmanlık Bölümü, esratanboga@yahoo.com 


\section{Abstract}

In a rapidly changing world, it is impossible to shape education environment of contemporary children by teachers' previous knowledge. It is a known fact that teachers who follow innovative methods and techniques on education, use games and activities for in-class and out-class implementations, use information technologies actively, value colleagues' cooperation and sharing knowledge can create more efficient learning experiences. On the other hand, in service teacher training studies in Turkey focus more on theoretical information than practice. With this in mind, the purpose of this study is to develop a workshop model which can provide more active internal knowledge sharing processes. This study was conducted at a primary school in Istanbul as a part of vocational studies during June 2015. To design workshop studies, personal information forms that identified teachers' vocational qualifications and requirements and focus group interviews were used. The attending teachers designed activities and games for 11 different topics. Workshops were performed for two different groups which consisted of 19 teachers each on a rotation basis.

After two weeks of workshop studies, education evaluation survey was realized. It was found that workshop studies were found useful and helpful by participant teachers. Further studies like the one in this study that take into account internal education requirements and use internal human resources can help promote teacher professional development.

Keywords: The workshop model, internal sharing knowledge, teacher education

\section{Giriş}

Küreselleşmenin de etkisi ile değişime olan ihtiyaç gün geçtikçe artmakta, bu değişim eğitim kurumlarının da değişmesi gerekliliğini gündeme getirmektedir. Değişimin yakalanması, öğretmenlerin tekdüze yöntemler yerine; öğretme durumlarını ustalık ile düzenlemesi, öğrenciyi odak noktaya alarak öğrencinin girişimciliğini ve sorumluluğunu geliştirebilmesi ile mümkündür (Budak ve Demirel, 2003, s.64).

Çağdaş öğrenme sürecine göre öğrenmenin ana elemanı öğretmen değil öğrencidir. Öğretmenin görevi öğrencinin bilişsel aktivitelerini arttırmada ona rehberlik etmektir. Bu da öğretmenin her şeyi bilen ve bildiklerini aktaran anlayış içerisinden çıkıp, bilgisini paylaşan ve karşıdakinde paylaşma isteği uyandıran; eksikliklerinin farkında olan ve bu eksiklikleri tamamlama yollarını arayan kişi olması ile mümkündür (Işık, Çiltaş ve Baş, 2010, s.59). Düşünen, eleştiren, yaratıcı ve bilgiye ulaşma yollarını bilen öğrenciler yetiştirmeye çalışan öğretmenler; okulu iyileştiren, problemleri çözebilen, öğrencilerin aktif katılımını sağlayan, yol ve yön gösteren bir kaynaktır (Özen, 2006, s.142).

Alkan (1976) öğretmenin sahip olması gereken yetenekleri beş başlıkta özetler. Bunlardan ilki genel eğitimdir. Genel eğitim, öğretmenin görevini yapmak için gerekli kişilik özelliklerini ve genel kültür bilgisini içerir. İkinci boyut öğretme alanına ilişkin öğretmenin yeteneklerini ve bilgisini içerir. Üçüncü boyutta öğretmenin eğitim bilimine dair teorik yeterlilikleri, dördüncü boyutta teknoloji ve uygulama yönü ile ilgili yetenekleri bulunmaktadır. Son boyutta 
ise öğretmenin bu dört alanda senteze gidebilmesi, bu yeterliliklerini özel durumlarda belirli amaçlara göre kullanabilmesi yer alır. Whitehurts (2002) ise etkili öğretmenlerin özellikleri arasında öğretmenlerin alan bilgisini, genel bilgi ve yetenekleri, deneyimleri, lisans üstü dereceleri, mesleki gelişime odaklaşma ve yoğunlaşmayı sıralar. Öğrenci başarısında en etkili olan öğretmen özelliği birinci derecede bilişsel yetenek iken, ikinci sırayı mesleki gelişime odaklanma almaktadır. Sırası ile deneyim, içerik bilgisi, sertifikalar, lisansüstü dereceler ve atölye çalışmaları öğrenci başarısına etki eden diğer faktörler olarak sıralanmaktadır.

Seferoğlu (2004) iyi bir öğretmeni "kendisini mesleki ve kişisel açılardan sürekli geliştiren, kendisini geliştirmeye yönelik fırsatları ve olanakları araştıran ve değerlendiren öğretmen” olarak tanımlar. Farklı yaş grupları, sosyo-ekonomik düzey, gelişim düzeyi ve hazır bulunuşluklar ile gelen öğrencilere karşın öğretmenin, farklı yaklaşım, yöntem ve teknikleri kullanması gerekmektedir. Bu durum ancak öğretmene sağlanacak sürekli bir destek ile mümkün olabilir. Bu destek, öğretmenlerin mesleki gelişim süreçlerinin; sürekli sorgulanması, bugünün ve geleceğin gerektirdiği nicelik ve niteliklere göre sürekli iyileştirilmesi ile mümkün olacaktır (Azar, 2011, s.36). Örgütsel iyileştirmenin temelinde ise günümüz bilgi toplumunun gerekliklerinin farkında olan ve bilgisini paylaşan öğretmenler yer almaktadır.

Günümüz bilgi toplumunda öğretmen rolleri bilgi, teknoloji ve sosyal değerlerdeki değişimlere paralel olarak değişim göstermektedir. Demokratikleşme, farklılıklara saygı, yeteneği fark etme ve geliştirme, insan hakları, eşitlik ön plana çıkan değerler arasındadır. Bilgi toplumu öğretmenleri, eğitim teknolojilerini iyi kullanabilen, kendi uzmanlık alanına hâkim, öğretim program ve yöntemlerini sorgulayarak mevcut sınıf ortamına göre yeniden tasarlayabilecek, sürekli öğrenen kişiler olmalıdır (Genç, 2000, s.383-384). Bu durum eğitim kurumlarında mesleki gelişimin önemini arttırmaktadır.

Eğitim sistemimizdeki pek çok uygulama öğretmenlerin niteliğinin sorgulanmasına neden olmaktadır. Milli Eğitim Bakanlığı, 1990’larda öğretmen açı̆̆ını kapatmak için, mezuniyet alanına bakmaksızın çok sayıda kişiyi sınıf öğretmeni olarak atamıştır. Sadece 1998 yılında, eğitim fakültesi mezunları dişında 41 bin öğretmen atanmıştır (Başkan, 2001, s.16). Diğer taraftan öğretmen yetersizliği nedeni ile asaleten atanamayan ya da branşı öğretmenlik olmamasına rağmen ücretli olarak öğretmenlik yapan 70.000 üzerinde öğretmenimiz bulunmaktadır (Habertürk, 2015). Tüm bu durumlar düşünüldüğünde mesleki gelişim süreçlerinin önemi bir kez daha anlaşılmaktadır.

Milli Eğitim Bakanlığı (2006) öğretmenlik mesleği genel yeterlilikleri arasında 1. yeterlilik olarak mesleki gelişim alanını verir. Bu yeterliliğin alt yeterliliği olan "mesleki gelişmeleri izleme ve katkı sağlama yeterliliğì" inde öğretmenlerin mesleki gereksinimlerinin farkına vararak; mesleki gelişim planı hazırlamaları, bu plan çerçevesinde ilgili hizmetiçi eğitim seminer toplantı vb. çalışmalara katılmaları, ilgili yayınları takip etmeleri gerekmektedir. 
Türkiye'de mesleki gelişim çalışmalarının temelini "hizmetiçi eğitim” ler oluşturmaktadır. Kamu kurumlarında ya da özel kurum kuruluşlarda çalışan her seviyede personele, işe başladıklarından emekli oluncaya kadar işe uyum, işte verimliliklerini arttırma, bilgi ve görgülerini tazeleme, yeni görevlere uyumlarını ve gelecekteki görevlere hazırlanmalarını sağlama amacı ile yapılan eğitimlere "hizmetiçi eğitim" denilmektedir (MEGSB, 1988). Ülkemizde planlı hizmetiçi eğitim çalışmaları 1960 yılında, Milli Eğitim Bakanlığı’nda “Öğretmeni İşbaşında Yetiştirme Bürosu’nun kurulması ile başlamıştır. 1975 yılında bu büro, "Hizmetiçi Eğitim Daire Başkanlığı" na dönüştürülmüştür. Hizmetiçi Eğitim Dairesi hizmetiçi eğitim ihtiyaçlarını hizmetiçi eğitim merkezlerinde düzenlenen bir ya da iki haftalık kurslar ile karşılamaya çalışmaktadır (Bedük, 1997). Ülkemizde hizmet öncesi öğretmen eğitimi ise 1982 yılından beri Milli Eğitim Bakanlığı ile işbirliği içinde üniversiteler tarafından yapılmaktadır (Kavak, 1999, s.313).

Ülkemizde öğretmenlere yönelik Milli Eğitim Bakanlığı tarafından düzenlenen mesleki gelişim programları temel eğitim, hazırlayıcı eğitim ve pratik eğitimler olmak üzere 3 başlıktadır. Kurslar merkezi ve mahalli olarak yürütülmektedir. Programların süresi 1 gün ile 1 yıl arasında değişmek ile birlikte, çoğu 5 ila 12 gün arasında sürmektedir. Tüm yıl içine yayılmış olan programların yaz döneminde daha yoğun olduğu görülmektedir (MEB, 1995; MEB, 2000). Mevcut tasarlanan mesleki gelişim programlarının daha merkezi olduğu, farklı okullarda yapılması nedeni ile katılımın zor sağlandığı, zorunlu-gönüllü uygulamalar ile her okulda 1-2 kişinin dahil edildiği gözlenmektedir. Ancak bu eğitimler sonrasında, eğitim sırasında yapılan çalışmaların okul geneline yaygınlaştırılamadığı da bilinen bir gerçektir. Diğer yandan eğitimi veren uzmanları eğitim içeriğini daha çok teorik bilgi ile doldurmaları ve uygulamalara yer vermemeleri, eğitime dahil olan öğretmenlerin eğitim içeriğini okula yansıtmasını kısıtlamaktadır. Tüm bu gerekçeler dahilinde öğretmenlerin mesleki gelişim çalışmalarının bilgi çağına, 21. yüzyıl öğretmen yeterliliklerine, çalışılan öğrenci grubuna, yerel özelliklere ve ihtiyaçlara göre planlanması ön plana çıkmaktadır.

Yapılan mesleki gelişim çalışmalarının planlama ve organizasyon aşaması kadar, sürecin değerlendirilmesi de önemlidir. Bu nedenle süreç öncesinde eğitimin amaçlarının açık ve net olarak belirlenmesi, istenilen sonuçlara ulaştıracak metotların seçimi, mesleki gelişim çalışmalarının sonuçlarının öğretmenin sınıf içi uygulamalarına yansıyıp yansımadığı ve tüm bu yapılanların eğitimin kalitesine etkisi net olarak ortaya konulmalıdır (Flanders, 1963, s.25-26). Tasarlanan mesleki gelişim çalışmalarının birbirine ışı tutacak ve birbirini tamamlayacak şekilde kurgulanması gerekliliği de diğer önemli noktadır. Verilen eğitim içeriklerinin meslektaşlarla paylaşılması; meslektaş dayanışması, işbirliğine dayalı öğrenme ve atölye çalışmaları ile desteklenmesi öğrenmeyi kalıcı hale getirecek ve öğrenilen bilgilerin yaygınlaşmasını sağlayacaktır.

“Devamlı Öğrenme” kitabında Loucks Horsley (1987) başarılı bir öğrenme geliştirme programında bulunması gereken özellikleri şöyle sıralamışlardır: 
- Birlikte problem çözme ve işbirliği,

- Deneysellik (sınıfı laboratuar olarak görme) ve risk alma,

- Bilgi kaynaklarına ulaşmada kurumsallaşma,

- Hedef belirleme, uygulama, değerlendirme ve karar vermede uygun katılımcıların dahil edilmesi,

- Yeni öğrenme süreçleri ile eğitim çalışmalarının zamanlamasına dikkat edilmesi, liderlik ve devam eden yönetimsel destek,

- Uygun teşvik ve ödüllendirmeler,

- Eğitimin yetişkin öğrenmesi prensiplerine uygun tasarlanması,

- Bireysel hedeflerin okul ve bölge hedefleri ile bütünleştirilmesi,

- Bölgenin ve okulun örgütsel yapısı ve felsefesine göre programın oluşturulması.

Etkili mesleki gelişim çalışmaları tek bir konuya odaklanmalı, katılan öğretmenlerin ihtiyaçlarına yoğunlaşmalı, devamlı ve sürdürülebilir olmalı, öğretmenin gerçek yaşamda karşılaştığı problemlere çözümler bulmalı, katılımcılar için anlamlı olmalı, katılımcılar arasında işbirliğine dayalı ilişkiler geliştirmeli, katılımcıları öğrendiklerini yansıtmaları konusunda cesaretlendirmelidir (Bayrakçı, 2009, s.11). Özer (2004) pek çok öğretmenin mesleki gelişime ihtiyaç duyduğunu belirtmesine rağmen, yalnızca çok az öğretmenin mesleki gelişim çalışmalarına gönüllü katıldığını bulmuştur. Mesleki gelişim çalışmalarına katılan öğretmenlerin bu eğitimlere ilişkin görüşlerini inceleyen Özen (2006) ise öğretmenlerin eğitim programlarını gerekli ve yararlı bulduklarını ancak; mesleki gelişim çalışmalarında öğreticilerin uzman olmaması, uygulamanın gayri ciddi olması, anlatılanların kuramsal olması, uygulamanın olmaması ya da çok az olması, programın zamanlamasının uygun olmaması, fiziksel ve teknolojik olanakların yetersizliği, öğrenilenlerin paylaşılmaması gibi pek çok sorunun olduğunu belirtmiştir. Bayrakçı (2009) Türkiye’deki mesleki gelişim çalışmalarını değerlendirdiği araştırmasında mesleki gelişim çalışmalarında en önemli güçlükleri, profesyonel çalışan eksikliği, öğretmenler arasında işbirliğinin olmaması, geribildirimin olmayışı ve sistemli bir mesleki eğitim modelinin olmayışı olarak sıralamıştır.

Özcan ve Bakioğlu (2010) okul yöneticilerinin mesleki gelişim çalışmalarına katılmalarının görevlerine olan etkilerini inceledikleri meta analitik çalışmada, mesleki gelişim çalışmalarına katılmamış olmanın göreve etkisini düşük düzeyde bulmuşlardır. Budak ve Demirel'in (2003) çalışmaları göstermektedir ki, mesleki gelişim çalışmalarına katılan öğretmenler ile katılmamış olan öğretmenlerin eğitim ihtiyaçları arasında anlamlı bir fark görülmemektedir. Öğretmenlerin özellikle eğitim-öğretim planı hazırlama, özel eğitim ve eğitim teknolojisi alanlarında desteğe ihtiyacı vardır. Araştırmacılar öğretmen eğitimi konusunun yeniden gözden geçirilmesi, Milli Eğitim Bakanlığı tarafından öğretmenlerin meslekleri ile ilgili gelişmeleri izleyebilecekleri bir sistemin olması gerekliliğini belirtmişlerdir.

Mesleki gelişimde alternatif uygulamalara bakıldığında sürekliliği olan, teori ve uygulamayı birlikte veren, kursiyerlerinin birbirlerini gözledikleri, görüş alışverişinde bulundukları, 
mentörlük ve işbaşında yetişmenin olduğu uygulamalardaki öğrenmelerin daha kalıcı olduğu ve sınıf ortamında uygulandığ 1 görülmektedir (Özen, 2006, s.143). Araştırmalar uygulanan mesleki gelişim programlarının etkili olabilmesinde kurum dışından gelen danışmanların yerine kurum içinden sağlanan katılımların, okul temelli mesleki deneyim paylaşımlarının daha yararlı olduğunu göstermektedir. Sorunları bizzat yaşayan öğretmenler daha gerçekçi saptamalar yapabilecek, daha uygulanabilir çözüm önerileri sunabileceklerdir. Öte yandan mesleki gelişim süreçlerinde karar verici olan ve katkı sağlayan öğretmenler programı sahiplenecek ve programın verimi için daha çok çaba harcayacaklardır (Seferoğlu, 2004, s.42). Tüm bu veriler ışı̆̆ında “Atölye Çalışması Modeli” ile daha etkili ve verimli, uygulamaya dönük bir mesleki gelişim çalışmasının faydalı olacağı düşünülmektedir.

Atölye çalışması modeli klasik anlatılardan ziyade uygulamalı etkinlikleri içeren, takım çalışmasını ve etkili iletişimi esas alan bir eğitim şeklidir (Lumpe, 2007, s.125; Gosser vd., 1998, s.185). Özellikle yeni becerilerin ve davranış değişikliğinin hedeflenildiği alanlarda, atölye çalışması modeli aktif olarak kullanılır (Russsel vd. 1978, s.10). Farklılaşan eğitim programları ve yapılandırmacı yaklaşım ile öğretmen eğitimlerinde de atölye çalışması modelinin gün geçtikçe daha fazla kullanıldığı görülmektedir (Zarske vd., 2004). Atölye çalışması planlanırken öncelikle çalışma sonunda katılımcılara kazandırılmak istenen hedef davranışlar belirlenir. Hedef davranışların katılımcıların iş tanımları ve gereksinimleri düşünülerek belirlenmesi gerekmektedir. Atölyelerin tasarımı sırasında katılımcıların yaş, deneyim gibi demografik özellikleri ile hazırbulunuşluk düzeyleri dikkate alınır. Katılımcıların birbirinden öğrenebileceği, sürece aktif olarak dahil olabileceği ortamların yaratılması esastır (Fox vd., 2003, s.24). Atölye çalışmasını yöneten liderin iletişim ve problem çözme becerilesi yüksek, takım çalışmasına inanan, aktif katılımı destekleyen ve esnek uygulamalara yer verebilen nitelikte olması gerekmektedir (Gosser vd., 1998, s.185-186). Çalışmanın bilimsel temellere dayalı olması, iyi planlanması, yer seçimi, materyallerin önceden hazırlanması ve mutlaka çalışma sonuçlarının değerlendirilmesi önemlidir (Sabir vd., 2006, s.883). Tüm bu gerekçeler doğrultusunda, bu çalışmanın amacı, öğretmenlerin mesleki gelişimi için atölye çalışması modeline dayalı bir uygulamanın geliştirilmesi ve değerlendirilmesidir.

\section{Yöntem}

Araştırma modeli: Bu araştırma nicel ve nitel araştırma yöntemlerinin birlikte kullanıldığ karma modelli bir araştırmadır. Araştırma ile daha önceden belirlenmiş bir kuramsal çerçeve içinde bir uygulamanın test edilmesi ve değerlendirilmesi amaçlanmıştır. Kuramsal çerçeveye hakim olarak geliştirilen atölye çalışması modelinin uygulama süreci detaylı betimlenmiş ve bu süreç araştırmacı tarafından analiz edilerek uygulamaya yönelik bir değerlendirme yapılmıştır.

Katılımcılar: Araştırmanın katılımcıları İstanbul ilindeki bir ilkokulda çalışmakta olan 35 sınıf öğretmeninden oluşmaktadır. Katılımcı öğretmenler 23-55 yaş aralığındadır. Katılımcıların yaş ortalaması 35,3’ dür. Öğretmenlik mesleğindeki kıdemleri ise 2 ila 34 yıl 
arasında değişiklik göstermektedir. Ortalama kıdem 12,4 yıldır. 35 öğretmenden 11’i erkek, 24 'ü kadındır. Katılımcı olan sınıf öğretmenlerinden atölyelerin geliştirilmesi ve uygulanması sürecinde de destek alınmıştır.

Atölye çalışmasının geliştirilmesi ve uygulanmast: Öğretmenlerin mesleki gelişimini hedef alan atölyelerin geliştirilmesi sırasında, öncelikle 6 kişilik bir grupla odak grup görüşmesi yolu ile ihtiyaç analizi yapılmıştır. İhtiyaç analizi sonrası tespit edilen temalara yönelik eğitim içeriğini geliştirebilecek öğretmenlerin tespiti yoluna gidilmiştir. Daha öncesinde öğretmenler tarafından doldurulmuş kişisel bilgi formlarından (Ek1) yararlanılarak, hangi konuda hangi öğretmenin atölye oluşturacağına birlikte karar verilmiştir. Bu karar alınırken öğretmenlerin kişisel bilgi formlarında belirttikleri "almış oldukları sertifikalı eğitimler", "katılmış oldukları projeler", “iyi oldukları alanlar” ve "katkı sağlayabilecekleri alanlar” başlıkları değerlendirilmiştir. Atölye sahibi öğretmenler ile içerik hazırlama ve beklenti toplantısı yapılmış, atölyelerin uygulama ağırlıklı olmasına özen gösterilmiştir. İhtiyaç duyulan 11 farklı konuda etkinlikler, uygulamalar ve oyunlar tasarlamışlardır. Eğitim süreci planlanmış (Ek2), 2015 Haziran ayı mesleki çalışmalar döneminde atölyeler 19'ar kişiden oluşan 2 farklı grupta 50 dakikalık iki oturumda dönüşümlü olarak gerçekleştirilmiştir. Üç örnek atölye çalışmasının içeriğine dair detaylı bilgi aşağıda verilmektedir.

Mesleğim ve Ben Atölyesi: Atölyenin amacı öğretmenlerin mesleki yeterliliklerini sorgulamalarını sağlamak ve geliştirilebilecek alanları ile ilgili eylem planı oluşturmalarına destek olmaktır. 50 dakikalık atölye çalışmasında öğretmenlere MEB’in tanımladığı mesleki yeterlilik temelinde kalem konuşur etkinliği ile yeterlilik detaylandırması yaptırılmıştır. 6 mesleki yeterlilik alanı başlı̆̆ı duvara asılmış, eğitimci tarafından rastgele gruplanmış 6 grup öğretmen sıralı ve süreli olarak kâğıtların başında dolaşmış, sessizce kalemlerini konuşturma yolu ile beyin fırtınası yapmışlardır. Tüm gruplar her kâğıda yeterlilik tanımlamalarını ve hatırlatıcı kavramları yazdıktan sonra etkinlik sonlandırılmıştır. Etkinlik çıtıları okunarak büyük grup ile paylaşılmış ve katılımcılardan 6 yeterlilik alanı için 10 üzerinden kendilerine puan vermeleri istenmiştir. Ardından katılımcılara öz değerlendirme yaparak en düşük puan verdikleri yeterlilik alanlarını 10 üzerinden kaça yükseltmek istedikleri sorulmuştur. Ve katılımcılardan bunu nasıl yapacaklarına dair eylem adımlarını yazmaları istenmiştir. Çalışmanın sonunda ise katılımcılar hedeflerini, eylem adımlarını, hedefe ulaşmadaki riskleri ve bu risklerle baş edebilme yollarını büyük grup ile paylaşmışlardır (Ek-4).

Ben Çocuğum Atölyesi: Atölyenin amacı öğretmenlerin çocuk haklarına dair farkındalık oluşturmasını sağlamak ve çocuk hakları ile ilgili sınıflarında yapabilecekleri örnek uygulamaları öğretmenlerle paylaşmaktır. Çalışma içerisinde öncelikle beyin fırtınası yöntemi ile hak ve çocuk kavramı üzerinde durulmuştur. Ardından çocuk hakları sözleşmesi maddelerinden yola çıkılarak, seçilen bazı maddelerin gruplar içerisinde resmedilmesi ve paylaşımlı okuma yapılan madde detaylarının büyük grup ile paylaşılması sağlanmıştır. Sonrasında da bu maddelerin çocuklara ve velilere nasıl anlatılacağı ile ilgili örnek etkinlik oluşturmaları istenmiştir. Grupların örnek etkinlikleri büyük grup ile paylaşmasının ardından çalışma sonlandırılmıştır. 
Hikayelerin Gücü Atölyesi: Atölyenin amacı hikaye anlatıcılığının eğitimdeki yerine dair katılımcılarda farkındalık sağlamak ve katılımcıları uygulama yapıcı hale getirmektir. Etkinlikte öncelikle hikayelerin eğitimde kullanıldığı temel alanlar katılımcılar ile paylaşılmıştır. Ardından ortak hikaye yazma, var olan resimlerden hareket ederek hikaye ortaya çıkarma, verilen anahtar kelimelerden yola çıkarak hikaye oluşturma gibi teknikler kullanılarak katılımcıların hikaye oluşturmaları sağlanmıştır. Örnek uygulamalar ve soru-cevap yöntemi ile çalışma zenginleştirilmiştir.

Veri toplama araçları: 2 hafta süren atölye çalışmalarının ardından katılımcı öğretmenlere araştırmacılar tarafından uzman desteğine başvurularak hazırlanan «eğitim değerlendirme anketi» (Ek3) uygulanmıştır. Anket "tamamen katılıyorum” dan "hiç katılmıyorum” a doğru 5’li likert formunda 11 maddeden ve 3 açık uçlu sorudan oluşmaktadır. Anket araştırmacı tarafından 3 alan uzmanının görüşüne başvurularak hazırlanmıştır.

Verilen toplanması: Atölye çalışmalarının etkililiğini sınamak amacı ile geliştirilmiş «eğitim değerlendirme anketi» 35 katılımcıya, atölye çalışmalarının bitiminde, sınıf ortamında yüz yüze uygulanmıştır. Katılımcılardan atölyelerin niteliğine, eğitmenin yeterliliğine, fiziksel ortama ve kullanılan materyallere dair görüşlerini belirtmeleri istenmiştir. Verilerin toplanması sırasında, açık uçlu soruların önemine vurgu yapılmıştır.

Verilerin çözümlenmesi: Yanıtlanmış olan 35 anketten tamamı değerlendirmeye alınmıştır. Anketlerin değerlendirilmesi SPSS paket programının 17.00 versiyonu ile yapılmıştır. Verilerin analizinde betimsel istatistik tekniklerinden yararlanılmıştır. Açık uçlu soruların değerlendirilmesinde ise içerik analizi yöntemi kullanılmıştır. İçerik analizi sırasında açık uçlu sorulardan elde edilen ham veriler temel alınarak, ana kategoriler/temalar oluşturulmuş, bu temalar altında verilen yanıtların sıklık düzeyleri değerlendirilmiştir. Temalar belirlenirken temaların verilen tüm yanıtları kapsamasına dikkat edilmiştir. Yanıtların yalnızca bir tema altında yer almasına ve temaların birbirinden bağımsız olmasına özen gösterilmiştir. Verilerin değerlendirilmesi sırasında katılımcıların verdikleri yanıtlar, araştırmanın amacına uygun ve nesnel olarak sınıflandırılmıştır.

\section{Bulgular}

Araştırma bulgular değerlendirildiğinde anket maddelerinden en yüksek puanı sırası ile "Eğitmen arkadaşlar konularına hazırlıklı idi.", "Atölye çalışmaları uygulamaya dönüktü.”, “Eğitmen arkadaşlar konularına hakimdi.” maddelerinin aldığı görülmektedir. En düşük puanlamalar ise sırası ile "Çalışmalar sırasında verilen dokümanlar, kaynaklar yeterliydi.", "Atölye çalışmasının fiziksel ortamı (sınıf, masa vb.) uygundu., "Çalışma sırasında kullanılan materyaller yeterliydi.” maddeleri için yapılmıştır. Ancak tüm maddelerin ortalama puanlarının 5 üzerinden 4.50 ve üzerinde olduğu görülmektedir (Tablo 1.) 
Öğretmenlerin mesleki gelişimi için atölye çalışması modeline dayalı bir uygulamanın geliştirilmesi ve değerlendirilmesi

\section{Tablol}

Anket Maddelerine Verilen Yanıtların Ortalama Değerlerine Ilişkin Betimsel Istatistik Sonuçları

\begin{tabular}{clcc}
\hline Sıra No & Madde & Ortalama & Standart Sapma \\
\hline 1 & Seminer konuları iyi seçilmişti. & 4.62 & .49 \\
2 & Atölye çalışmaları uygulamaya dönüktü. & 4.70 & .46 \\
3 & Etkinliklerin süresi yeterliydi. & 4.58 & .49 \\
4 & Eğitmen arkadaşlar konularına hakimdi. & 4.68 & .47 \\
5 & Eğitmen arkadaşlar konularına hazırlıklı idi. & 4.71 & .51 \\
6 & Yapılan çalışmaları sınıf içinde uygulayabilirim. & 4.58 & .55 \\
7 & Atölye çalışmaları yeni teknik ve beceriler öğrenmemi sağladı. & 4.57 & .55 \\
8 & Atölye çalışmasının fiziksel ortamı (sınıf, masa vb.) uygundu. & 4.50 & .50 \\
9 & Çalışmalar sırasında verilen dokümanlar, kaynaklar yeterliydi. & 4.48 & .50 \\
10 & Çalışma sırasında kullanılan materyaller yeterliydi. & 4.54 & .50 \\
11 & Bu tarz atölye çalışmalarının okulumda tekrarlanmasını isterim & 4.63 & .54 \\
\hline
\end{tabular}

Katılımcıların, anket formunda bulunan açık uçlu sorulara verdikleri cevaplar soru bazında ayrı ayrı incelenmiş, her bir soru için öncelikle ana temalar ve bu ana temaları şekillendiren alt temalar belirlenmiştir. Ulaşılan bulgular aşağıda sunulmuştur.

Katılımcıların "En yararlı bulduğunuz atölye çalışması hangisidir?” sorusuna verdikleri yanıtlar onay ve konu başlıkları olmak üzere 2 ayrı temada toplanmıştır. Aynı yanıtı veren katılımcı sayısı, ifadelerin sonunda parantez içerisinde belirtilmiştir. Onay temasında 7 katılımcı "Yapılan tüm çalışmaları faydalı buluyorum" (7) demiştir. Konu Başlıkları temasında ise sırası ile drama (15), fen bilgisi etkinlikleri ve deneyler (7), sportif ve fiziksel etkinlikler (7), müzik algisı (6), hikaye anlatıcılığ 1 (6), zihin haritalama (4), mesleğim ve ben (3), matematiksel modelleme (3), görsel sanatlar etkinlikleri (1) atölye çalışmaları en yararlı bulunmuştur.

Katılımcıların “Atölye çalışmalarını siz planlasaydınız neyi daha farklı yapardınız?” sorusuna verdikleri yanıtlar genel süreç, yeni konular ve onay olmak üzere 3 ayrı temada toplanmıştır. Genel süreç temasında "teorik açıklamalara daha az yer verirdim" (1), "sinema gösterimi yapardım" (1), "oyun çeşitlerini zenginleştirirdim” (1), “yapılan çalışmalarla ilgili dokümanların bize ulaştırılmasını isterdim” (1), "araç-gereç ve materyal desteği ile zenginleştirirdim” (2), "zümrelere göre farklı çalışmalar yapılabilirdi” (1), "bilişim ve interneti eğitimde kullanma konusuna yer verirdim” (1) yanıtları alınmıştır. Yeni konular temasında katılımcılar, bireysel farklılıkları nasıl yöneteceğimize dair konular yerleştirirdim (1) ve drama etkinliğinde İngilizce konu seçerdim (1) yanıtlarını vermişlerdir. Son olarak onay temasında ise "Çok güzel planlanmıştı, geliştirmeye gerek yoktur” (11) yanıtının ağırlıklı olarak verildiği görülmektedir. 
Katılımcıların “Önümüzdeki yıl programa almamızı istediğiniz konular nelerdir?” sorusuna verdikleri yanıtlar tek temada toplanmıştır. Bu temayı oluşturan ifadeler; öğrenciyi tanıma ile ilgili psikolojik içerikler (1), serbest zaman etkinlikleri ve oyunları (1), bireysel farklılıkları yönetme (1), İngilizce branşına yönelik çalışmalar (1), kitap okuma ve tartışma etkinliği (1), mevcut konuların derinleştirilmesi (1), zeka geliştirici oyunlar (1), zamanı etkili ve verimli kullanma (1), Türkçe dersinde yapılabilecek örnek okuma etkinlikleri (1), sınıf yönetimi (1), sınıfta öğrenci ile iletişim (1), bilişim ve kişisel gelişim konuları (1), 1. sınıflara yönelik sınıf içi etkinlik örnekleri(1), özel yetenekli öğrencilere yönelik sınıf içi uygulamalar (1), matematik dersine yönelik atölye çalışmaları (1), yetenek keşfetme yöntemleri(1) olarak sıralanmaktadır.

\section{Tartışma ve Öneriler}

$\mathrm{Bu}$ çalışmanın öğretmenlerin mesleki gelişimi için atölye çalışması modeline dayalı bir uygulamanın geliştirilmesi ve değerlendirilmesi amacı ile yapılmıştır. Atölye çalışması sonrasında uygulanan değerlendirme anketine verilen yanıtlar göstermektedir ki; atölye çalışmaları katılımcılarca çok faydalı ve uygulamaya dönük bulunmuştur. Katılımcılar atölyeleri hazırlayanların konulara hakim olduğunu ve iyi hazırlandıklarını belirtmektedir. Ancak katılımcılar, çalışmalar ile ilgili daha fazla doküman ve kaynak verilmesi, atölye çalışmasının fiziksel ortamının daha özenli seçilmesi gerektiğini belirtmişlerdir. Bu durum öğrenme ortamının etkili öğrenme üzerinde etkili olduğu düşüncesini desteklemektedir. Ayrıca katılımcıların daha fazla kaynak ve uygulama materyali beklentisi, söz konusu kazanımları netleştirmeleri ve sınıflarına döndüklerinde uygulamaları daha rahat yapabilmeleri için anlamlıdır.

Katılımcıların açık uçlu sorulara verdiği yanıtlara bakıldığında; en yararlı atölye çalışmalarının başında "drama” etkinliklerinin geldiği görülmektedir. Eğitimde drama uygulaması öğrencilerin; başkaları gibi düşünebilme, problem çözme, yaratıcılık, farklı görüşler ortaya koyabilme, diğerlerine karşı kişisel görüşlerini tahlil edebilme, tartışma, zihinsel kapasiteyi geliştirme, karar verebilme gibi bilişsel becerilerinin gelişimine katkı sağlamakta; duygularının farkına varma ve ifade edebilme, sosyal farkındalığı arttırma, arkadaşlık ilişkilerini geliştirme, ortak hareket etme, empati, kendine güven, dayanışma ve paylaşma duygusunun gelişimi, hoşgörülü olma gibi sosyal ve duygusal becerilerin gelişimini sağlamakta; oyun kurma ve oynama, yaşadığı olayları vücut hareketleri ile anlatmaya çalışma, vücudunu koordineli bir şekilde amaca uygun olarak kullanma becerisi ile de devinişsel becerilerinin gelişimine olanak tanımaktadır (Durdukoca, 2015, s.155). Bu nedenle öğretmenlerin mesleki gelişim programlarının düzenlenmesinde ve uygulanmasında mutlaka dramaya yer verilmelidir.

Katılımcılar en yararlı 2. atölye olarak "fen bilgisi etkinlikleri ve deneyler" atölyesini seçmişlerdir. Bilimsel süreç becerilerinin aşamalarından biri olan deney yapma; değişkenleri değiştirme ve kontrol etme sürecidir. Gerekli olan birçok araç gereci beceriyle kullanarak uygun bir düzenek kurmayı, değişkenleri değiştirip kontrol ederek veriler elde etmeyi, bu verileri kaydedip değerlendirerek model oluşturmayı, verileri yorumlamayı, sonuca varmayı ve yapılanları raporlaştırmayı içerir (Erdem vd., 2010, s.92). Deney sürecine dâhil olan öğrenci 
bilgiyi somutlaştırarak içselleştirir. Bu nedenle öğretmenlerin mesleki gelişim programlarının düzenlenmesinde ve uygulanmasında mutlaka deney çalışmalarına yer verilmelidir.

Katılımcıların en yararlı 3. atölye olarak seçtikleri atölye "sportif ve fiziksel etkinlikler" atölyesidir. Spor, toplumsal kültür içerisinde sosyal bir gerçeklik olarak yer almaktadır. Bu doğrultuda spor yaşamın her aşamasında bireyin toplumsallaşmasına etki eder. Ayrıca, günümüzde kitleleri peşinden sürükleyen spor, bireyin fiziksel, ruhsal, zihinsel ve sosyal gelişimine doğrudan ya da dolaylı olarak katkıda bulunmaktadır. Sportif etkinlikler kişisel ve sosyal kimlik hissi ve grup üyeliği duygusu vererek insanları bir araya getirir. Beden sağlığının yanı sıra, grup çalışması, dayanışma, hoşgörü, anlayış gibi kavramların oturmasına aracılık eder (Atalay vd., 2014, s.16). Öğrencilerin akıl, ruh ve beden sağlıklarının en önemli destekleyicisi olan sportif ve fiziksel etkinliklere öğretmenlerim mesleki gelişim programları içerisinde yer verilmesi uygun olacaktır.

Katılımcıların "Atölye çalışmalarını siz planlasaydınız neyi daha farklı yapardınız?" sorusuna verdikleri yanıtlar incelendiğinde; eğitim içeriklerinde daha fazla görsel materyal kullanılmasını istedikleri görülmektedir. Katılımcılar filmler, oyunlar ve zengin materyaller ile eğitimin daha verimli olacağını düşünmektedir. Bunun yanı sıra katılımcılar mesleki gelişim çalışmalarının aynı branştaki öğretmenleri bir araya getirerek yapılmasının daha faydalı olacağını düşünmektedirler. $\mathrm{Bu}$ durum zümre çalışmalarının eğitim kurumlarında daha etkin kılınması gerçeğini akla getirmektedir.

Katılımcıların “Önümüzdeki yıl programa almamızı istediğiniz konular nelerdir?” sorusuna verdikleri yanıtlar incelendiğinde sınıf yönetimine dair başlıklar ile etkinlik ve oyun temalarının ön plana çıktığı görülmektedir. Bu durum öğretmenlerin mesleki gelişimlerine katkı sağlamak istedikleri alanların farkında olduklarını ve gelişime açık olduklarını göstermektedir.

Öğretmenlerin mesleki gelişimi için atölye çalışması modeline dayalı bir uygulamanın geliştirildiği ve değerlendirildiği bu çalışma göstermektedir ki; kurumlar yalnızca kurum içi kaynaklarını kullanılarak mesleki gelişime katkı sağlayabilirler. Bu nedenle eğitim yöneticileri başta olmak üzere tüm karar vericilere, mesleki yeterlilik ve gereksinimlere uygun kurumsal hizmetiçi eğitim çalışmaları planlamaları ve uygulamaları önerilmektedir. Planlamalara yeterlilikleri ölçüsünde kurumda çalışan öğretmenleri dâhil etmek, yapılan çalışmaların tüm çalışanlarca kabulünü ve anlaşılırlığını kolaylaştıracaktır. Bu amaçla kurumların personel bilgi bankası oluşturmaları ve dönem dönem bu bankayı yenilemeleri önerilmektedir.

Hizmetiçi eğitim çalışmaları öncesinde ihtiyaç analizinin yapılması ve ihtiyaç duyulan temalarda eğitimlerin düzenlenmesi önemlidir. Söz konusu temaların kurumdan kuruma, yerelden merkeze, birimlerin özelliklerine göre farklılaşacağ d düşünülmektedir. Zamanın ve emeğin verimli kullanılabilmesi, farklılaşan ihtiyaçlara göre etkili çalışmaların yapılmasına bağlıdır.

Kurum içi kaynak kullanımının ve eğitimci yeterliliğinin olmadığı durumlarda, ilgili personelin eğitici eğitimi alması ya da üniversiteler, sivil toplum kuruluşları gibi paydaşlardan 
destek alınması etkili olacaktır. Temalar belirlenirken 21. yüzyıl öğretmen becerilerinin ve öğretmen yeterliliklerinin de değerlendirilmesi gerekmektedir.

Hizmetiçi eğitim çalışmalarının planlanması ve uygulanması kadar, izlenmesi ve değerlendirilmesi de önemlidir. Yapılan eğitimlerin öğrencilere ve okuldaki uygulamalara ne kadar yansıdığı ve yarattığı etki izlenilmelidir. İzleme çalışmaları bilimsel yolla yapılmalı, sonraki çalışmalara yol gösterecek nitelikte olmalıdır.

Sonuç olarak, öğretmenlerin mesleki gelişimi için atölye çalışması modeline dayalı bir uygulamanın geliştirilmesi ve değerlendirilmesi amacı ile yapılmış bu çalışmanın, farklı katılımcı gruplarında, farklı atölye tasarımları ile tekrarlanmasının faydalı olacağı düşünülmektedir. 
Öğretmenlerin mesleki gelişimi için atölye çalışması modeline dayalı bir uygulamanın geliştirilmesi ve değerlendirilmesi

\section{Kaynaklar}

Alkan, C. (1976). Öğretmen eğitimi. Ankara Üniversitesi Eğitim Bilimleri Fakültesi Dergisi, 9(1), 95-115.

Atalay, A., Yücel, A. S., \& Korkmaz, M. (2014). Ergonomi ve sporda ergonominin kullanım ve öneminin incelenmesi. Uluslar Arası Hakemli Mühendislik ve Fen Bilimleri Dergisi, 1(1).

Azar, A. (2011). Türkiye’deki öğretmen eğitimi üzerine bir söylem: Nitelik mi, nicelik mi. Yükseköğretim ve Bilim Dergisi, 1(1), 36-38.

Başkan, G. A. (2001). Öğretmenlik mesleği ve öğretmen yetiştirmede yeniden yapılanma. Hacettepe Üniversitesi Eğitim Fakültesi Dergisi, 20, 16-25.

Bayrakçı, M. (2009). In-service teacher training in Japan and Turkey: A comparative analysis of instutions and practices, Australian Journal of Teacher Education, 34(1), 9-22.

Bedük, A. E. (1997). Okullarda hizmetiçi eğitim planlanması yapılabilmeli ve uygulanmalıdır, Milli Eğitim Dergisi, 199, 7-8.

Budak, Y ve Demirel, Ö. (2003). Öğretmenlerin hizmetiçi eğitim ihtiyac1, Kuram ve Uygulamada Öğretmen Eğitimi, 33, 62-81.

Durdukoca, Ş. F. (2015). Okulöncesi öğretmen adaylarının bir ders ve öğretim tekniği olarak dramaya yönelik görüşlerinin incelenmesi, Erzincan Üniversitesi Eğitim Fakültesi Dergisi, 17(1).

Erdem, A., Uzal, G., \& Ersoy, Y. (2010). Türk fizik vakfı öğretmen eğitimi etkinlikleri: Mesleki gelişme program modelini değerlendirme. Türk Fen Eğitimi Dergisi, 7(1), 88-104.

Flanders, N. A. (1963). Teacher behavior and in-service programs. Educational Leadership, 21(1), 25-30.

Fox, J. A., Hatfield, J. P., \& Collins, T. C. (2003). Developing the curriculum transformation and disability workshop model. Curriculum Transformation and Disability: Implementing Universal Design in Higher Education, 23-39.

Genç, S. Z. (2000). Bilgi toplumunda öğretmen eğitimi. Kuram ve Uygulamada Eğitim Yönetimi, 6(3), 375386.

Gosser, D. K., \& Roth, V. (1998). The workshop chemistry project: Peer-led team-learning. Journal of Chemistry. Education, 75(2), 185.

Habertürk. (2015). “Türk Eğitim- Sen Türkiyede ücretli öğretmenlerin sayısını belirledi” Habertürk, 18.02.2015 (http://www.haberturk.com/gundem/haber/1044387-69-ilin-verilerine-gore-ucretliogretmen-sayisi-71-bin-960-oldu adresinden 19.10.2015 tarihinde indirilmiştir).

Işık, A, Çiltaş, A. ve Baş, F. (2010). Öğretmen yetiştirme ve öğretmenlik mesleği, Atatürk Üniversitesi Sosyal Bilimler Enstitüsü Dergisi, 14(1), 53-62.

Kavak, Y. (1999). Öğretmen eğitiminde yeni bir yaklaşıma doğru: Standartlar ve akreditasyon. Kuram ve Uygulamada Eğitim Yönetimi, 19(19), 313-324.

Loucks-Horsley, S. (1987). Continuing to Learn: A Guidebook for Teacher Development. USA: Office of Educational Research and Improvements.

Lumpe, A. T. (2007). Research-based professional development: Teachers engaged in professional learning communities. Journal of Science Teacher Education, 18(1), 125-128.

MEB. (1995). Milli Eğitim Bakanlığı aday memurlarının yetiştirilmelerine yönelik yönetmelik, MEB Tebliğler Dergisi, 2423, 49-62.

MEB (2000). Hizmetiçi Eğitim Planı, Ankara: MEB Hizmetiçi Eğitim Dairesi Başkanlığı.

MEB (2006). Öğretmenlik Mesleği Genel Yeterlilikleri, Öğretmen Yetiştirme ve Eğitimi Genel Müdürlüğü, Ankara. 
MEGSB. (1988). Hizmetiçi Eğitim, Kuruluş, Gelişme Ve Faaliyetler, Ankara: Milli Eğitim Gençlik ve Spor Bakanlığı.

Özcan, Ş. ve Bakioğlu, A. (2010). Bir meta analitik etki analizi: okul yöneticilerinin hizmetiçi eğitim almalarının göreve etkisi, Hacettepe Üniversitesi Eğitim Fakültesi Dergisi, 38, 201-212.

Özen, R. (2006). İlköğretim okulu öğretmenlerinin hizmetiçi eğitim programlarının etkilerine ilişkin görüşleri, Abant İzzet Baysal Üniversitesi Eğitim Fakültesi Dergisi, 6(2), 141-160.

Özer, B. (2004). In-service Training of Teachers in Turkey at the Beginning of the 2000s. Journal of In-Service Education, 30(1), 89-100.

Russell, M. G., Hey, R. N., Thoen, G. A., \& Walz, T. (1978). The choice of childlessness: A workshop model. Family Coordinator, 179-183.

Sabir, M., Breckman, R., Meador, R., Wethington, E., Reid, M. C., \& Pillemer, K. (2006). The CITRA research-practice consensus-workshop model: exploring a new method of research translation in aging. The Gerontologist, 46(6), 833-839.

Seferoğlu, S. S. (2004). Öğretmen yeterlilikleri ve mesleki gelişim, Bilim ve Aklın Aydınlı̆̆ında Eğitim Dergisi, $58,40-45$.

Whitehurst, G. J. (2002, March). Scientifically based research on teacher quality: Research on teacher preparation and professional development. In White House Conference on Preparing Tomorrow's Teacher.

Zarske, M., Sullivan, J., Carlson, L., \& Yowell, J. (2004, June). Teachers teaching teachers: Linking K-12 engineering curricula with teacher professional development. In Proceedings of the 2004 ASEE Annual Conference, Salt Lake City, UT. 


\section{Ek I: Öğretmen Bilgi Formu}

\section{USKUP ILKOKULU OGRETMEN BILGI FORMU}

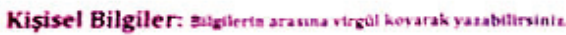

Ad. Soyad: Zehro ERCAN

Telefon Numarasi: 553 t65 645 e-posta adresi:zeherconagmall.

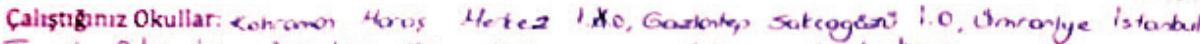

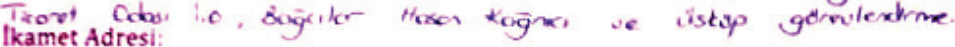

\section{Egitimsel/Mesleki Bilgiler:}

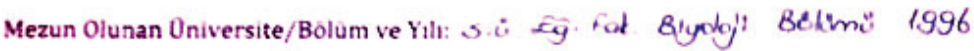

Varsa Yüksek Lisans ve Doktora/Yilı-Așaması: _ _

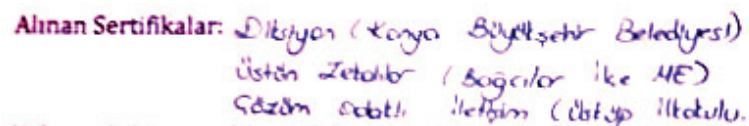

Yabana Dil Dũzeyi (Hangi Dil/Dùzey(Okuma, Yazma, Konușma)): inglluze ve Aropsa (orta)

Katulmış Olduğu Projeler/Projedeki Rolünüz: ENUER projes' (Enuer mostot tasorımı)

$$
\text { An Sinet th }
$$

Iş tecrübeniz (varsa çalıștı̆̆ınız diğer kurumlar/súre):

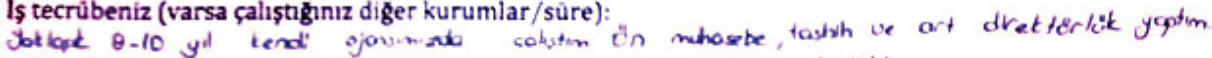

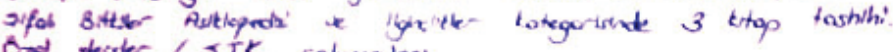

Cael decrite / STK colymotor,

Gûne ve Gelecelłe Dair:

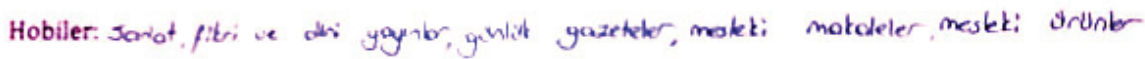
lyi Oldugunuz Alanlar: Heskgin, sowitual faliyetler, metin yazmi w tashh.

Geliștirmek Istediginiz Alanlar: Ko-hye ibona hoyalm

$$
\begin{aligned}
& \text { tbi tasorin ve torseptimi intenet bzeriden } \\
& \text { sotmo hoyo }
\end{aligned}
$$

Almak Istediginiz Egitimler: Dil it Kotyer

Mesleki ve Kișisel Hedefiniz (10 yll sonra nerede olmak istiyorsunuz): Ydreticl / Ùnlversitade Hoca. STK larda etlin / Jazar

Oskûpllkokulu'ndanbeklentiniz: Heskek: doyumu modder manen yosayobileceğm otode mik tosors, goksek bar dul chasin beklerin, isterin

Oskûp llk Okulu'na nasıl katkı sağlayabilirsiniz:

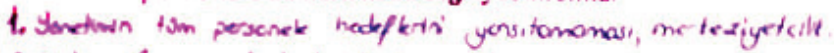

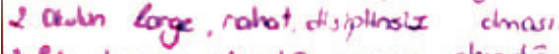

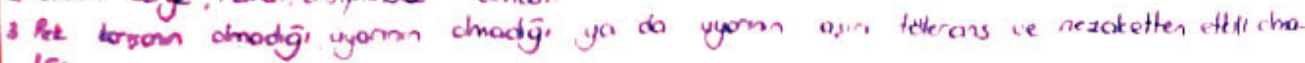

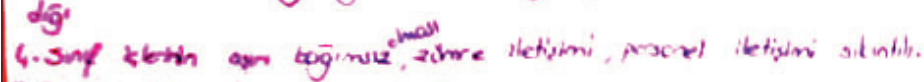

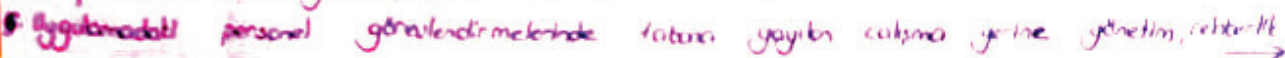




\section{Ek2: Eğitim Süreci Planlaması}

\begin{tabular}{|c|c|c|c|c|c|}
\hline $\begin{array}{l}\text { Sira } \\
\text { No }\end{array}$ & Tarih & Etkinlik & $\begin{array}{l}\text { Eğitmenler/Kolayl } \\
\text { aştırıcılar }\end{array}$ & Kaynaklar & Saat \\
\hline 1 & $\begin{array}{c}15.06 .2015 \\
\text { Pazartesi }\end{array}$ & Kahvaltı Etkinliği & Tüm Öğretmenler & Serpme Kahvaltı & $9.00-12.00$ \\
\hline 2 & $\begin{array}{l}16.06 .2015 \\
\text { Salı }\end{array}$ & $\begin{array}{c}\text { Zümre Değerlendirme } \\
\text { Toplantıları } \\
\text { YIL SONU DEĞERLENDIRME } \\
\text { KURULU }\end{array}$ & $\begin{array}{c}\text { Tüm Zümreler } \\
\text { Tüm Öğretmenler }\end{array}$ & $\begin{array}{c}\text { Zümre Tutanakları } \\
\text { Tutanaklar }\end{array}$ & $\begin{array}{r}9.00-9.45 \\
10.00-13.00\end{array}$ \\
\hline 3 & $\begin{array}{l}17.06 .2015 \\
\text { Çarşamba }\end{array}$ & $\begin{array}{l}\text { Sosyal Bilgiler ve Hayat } \\
\text { Bilgisinde Kavram Haritalama- } \\
\text { Temel Metot ve Örnekler } \\
\text { Fiziksel Etkinlik ve Oyun } \\
\text { Örnekleri }\end{array}$ & $\begin{array}{l}\text { Nezahat Karahan } \\
\text { Neşe Karaduman } \\
\text { Ümit Karaca } \\
\text { Bülent Tüner }\end{array}$ & $\begin{array}{l}\text { Etkinlik Örnekleri } \\
\text { Kavram Haritaları } \\
\text { Oyun örnekleri, } \\
\text { malzemeleri } \\
\text { Serbest rahat kıyafet }\end{array}$ & $\begin{array}{r}10.00-10.50 \\
11.10-12.00 \\
12.20-13.10\end{array}$ \\
\hline 4 & $\begin{array}{l}18.06 .2015 \\
\text { Perşembe }\end{array}$ & $\begin{array}{c}\text { Görsel Sanatlarda Sınıf içi } \\
\text { Etkinlik Örnekleri } \\
\text { Müzik Algısı-Basit Müzik Aleti } \\
\text { Yapımı }\end{array}$ & $\begin{array}{l}\text { Fadime Çiçek } \\
\text { Sonnur Tüner }\end{array}$ & $\begin{array}{l}\text { Etkinlik Örnekleri } \\
\text { Yapım Malzemeleri }\end{array}$ & $\begin{array}{r}11.00-11.50 \\
12.10-13.00\end{array}$ \\
\hline 5 & $\begin{array}{l}19.06 .2015 \\
\text { Cuma }\end{array}$ & Deneylerle Bilim & $\begin{array}{l}\text { Yasemin Altuntaş } \\
\text { Zehra Ercan }\end{array}$ & $\begin{array}{l}\text { Etkinlik Örnekleri } \\
\text { Deney Malzemeleri }\end{array}$ & $\begin{array}{l}11.00-11.50 \\
12.10-13.00\end{array}$ \\
\hline 6 & $\begin{array}{l}22.06 .2015 \\
\text { Pazartesi }\end{array}$ & $\begin{array}{l}\text { Sınıf İçi Drama Uygulamaları } \\
\text { Kendime Ayna Tutuyorum } \\
\text { (Mesleğim ve Ben) }\end{array}$ & $\begin{array}{l}\text { Emel Şahin- } \\
\text { Gürkan } \\
\text { Çolakkadıoğlu } \\
\text { Esra Töre }\end{array}$ & $\begin{array}{c}\text { Etkinlik Örnekleri } \\
\text { Etkinlik Materyalleri }\end{array}$ & $\begin{array}{r}11.00-11.50 \\
12.10-13.00\end{array}$ \\
\hline 7 & $\begin{array}{l}23.06 .2015 \\
\text { Salı }\end{array}$ & $\begin{array}{l}\text { Matematiksel Düşünme ve } \\
\text { Modelleme }\end{array}$ & $\begin{array}{l}\text { Halil Gözeller } \\
\text { Ümit Karaca }\end{array}$ & $\begin{array}{l}\text { Etkinlik Örnekleri } \\
\text { Modeller }\end{array}$ & $\begin{array}{l}11.00-11.50 \\
12.10-13.00\end{array}$ \\
\hline 8 & $\begin{array}{l}24.06 .2015 \\
\text { Çarşamba }\end{array}$ & $\begin{array}{c}\text { Sınıf İçi Drama Uygulamaları } \\
\text { Ben Çocuğum!.. (Çocuk Hakları } \\
\text { Örnek Uygulamaları) }\end{array}$ & $\begin{array}{l}\text { Selinay Göksu } \\
\text { Nazlı Şengül } \\
\text { Esra Töre }\end{array}$ & $\begin{array}{c}\text { Etkinlik Örnekleri } \\
\text { Etkinlik Materyalleri }\end{array}$ & $11.00-11.50$ \\
\hline 9 & $\begin{array}{l}25.06 .2015 \\
\text { Perşembe }\end{array}$ & $\begin{array}{l}\text { Çocukça Düşünme (Çocuk } \\
\text { Edebiyatı) } \\
\text { Hikayelerin Gücü (Hikaye } \\
\text { Anlatıcılığı) }\end{array}$ & $\begin{array}{l}\text { Halil Gözeller } \\
\text { Serpil Tozlu }\end{array}$ & $\begin{array}{l}\text { Etkinlik Örnekleri } \\
\text { Örnek Hikayeler } \\
\text { Okuma Listesi }\end{array}$ & $\begin{array}{l}11.00-11.50 \\
12.10-13.00\end{array}$ \\
\hline 10 & 26.06.2015 & Değerlendirme & Tüm Öğretmenler & Değerlendirme Formu & $9.00-13.50$ \\
\hline
\end{tabular}




\section{Ek3: Değerlendirme Formu}

\section{ÜSKÜP İLKOKULU \\ SEMINER ÇALIŞMALARI DEĞERLENDIREME ANKETI}

Sevgili Öğretmen Arkadaşım,

Bu anket okulumuzda 2014-2015 Haziran Dönemi Seminer Çalışmasını değerlendirmek amacı ile hazırlanmıştır. Ankete vereceğiniz yanıtlar çerçevesinde 2015-2016 Eğitim Öğretim Yılı eylül dönemi seminer programı hazırlanacaktır.

Yanıtlarınız tamamen gizlilikle incelenecek ve bu cevapların kimlere ait olduğu ile kesinlikle ilgilenilmeyecektir. Bu nedenle anketin üzerine isim yazmamanız rica olunur. İçten ve samimi vereceğiniz yanıtlar değerlendirmenin daha güvenilir olmasını sağlayacaktır.

Bu çalışmaya yaptığınız katkılar için teşekkür ederim.

Esra Töre

Psikolojik Danışman

Aşağıda 2015 yılı haziran seminer döneminde okulumuzda gerçekleştirilmiş seminer çalışmasına dair maddelere katıım derecenizi "tamamen katılıyorum" dan "hiç katılmıyorum" a doğru uzanan ölçek üzerinden sizin için en doğru seçeneğe çarpı $(X)$ işareti koyarak değerlendiriniz.

01 Seminer konuları iyi seçilmişti.

02 Atölye çalışmaları uygulamaya dönüktü.

03 Etkinliklerin süresi yeterliydi.

04 Eğitmen arkadaşlar konularına hakimdi.

05 Eğitmen arkadaşlar konularına hazırlıklı idi.

06 Yapılan çalışmaları sınıf içinde uygulayabilirim.

07 Atölye çalışmaları yeni teknik ve beceriler öğrenmemi sağladı.

08 Atölye çalışmasının fiziksel ortamı (sınıf, masa vb.) uygundu.

09 Çalışmalar sırasında verilen dokümanlar, kaynaklar yeterliydi.

10 Çalışma sırasında kullanılan materyaller yeterliydi.

11 Bu tarz atölye çalışmalarının okulumda tekrarlanmasını isterim

12 En yararlı bulduğunuz atölye çalışması hangisidir?

Atölye çalışmalarını siz planlasaydınız neyi daha farklı yapardınız?

Önümüzdeki yıl programa almamızı istediğiniz konular nelerdir? 
Ek4: Mesleğim ve Ben Etkinlik Formu

\section{Mesleğim ve Ben}

Geliştirmek İstediğim Özelliğim:

Şimdiki Durum(10 Üzerinden Puan veriniz):

Kaç Olmasını istersin:

Hedef Tanımlama: ( 1 yıl içinde mesleğin ile ilgili geliştirmek istediğiniz bir alan, özellik ya da yapmak istediğin bir şey)

S pecific (Özel)

M easurable (Ölçülebilir)

A ccepted (Kabul Edilebilir)

$\mathrm{R}$ ealistic (Gerçekçi)

T imely (Zamanlaması Olan)

Eylem Adımları:

1.

2.

3.

4.

5.

İhtiyacım Olan Kaynaklar:

Engellerim/Riskler:

Risklerim ve Engellerime dair eylem planım: 